\title{
In Vitro and In Vivo Characterization of 2-Deoxy-2-18 F- Fluoro-D-Mannose as a Tumor-Imaging Agent for PET
}

\author{
Shozo Furumoto ${ }^{1,2}$, Ryo Shinbo ${ }^{2}$, Ren Iwata ${ }^{2}$, Yoichi Ishikawa ${ }^{2}$, Kazuhiko Yanai ${ }^{1}$, Takashi Yoshioka ${ }^{3}$, \\ and Hiroshi Fukuda ${ }^{4}$ \\ ${ }^{1}$ Department of Pharmacology, Graduate School of Medicine, Tohoku University, Sendai, Japan; ${ }^{2}$ Department of \\ Radiopharmaceutical Chemistry, Cyclotron and Radioisotope Center, Tohoku University, Sendai, Japan; ${ }^{3}$ Department of Clinical \\ Oncology, Graduate School of Medical Science, Yamagata University, Sendai, Japan; and ${ }^{4}$ Department of Nuclear Medicine and \\ Radiology, Institute of Development, Aging and Cancer, Tohoku University, Sendai, Japan
}

2-Deoxy-2-18 F-fluoro-D-mannose ( $\left.{ }^{18} \mathrm{~F}-\mathrm{FDM}\right)$ is an ${ }^{18} \mathrm{~F}$-labeled mannose derivative and a stereoisomer of ${ }^{18} \mathrm{~F}-\mathrm{FDG}$. Our preliminary study demonstrated that ${ }^{18} \mathrm{~F}-\mathrm{FDM}$ accumulated in tumors to the same extent as ${ }^{18} \mathrm{~F}-\mathrm{FDG}$, with less uptake in the brain and faster clearance from the blood. However, detailed studies on the uptake of ${ }^{18} \mathrm{~F}$-FDM in tumors have not been conducted. We undertook this study to establish a practical method of ${ }^{18} \mathrm{~F}-\mathrm{FDM}$ synthesis based on an ${ }^{18} \mathrm{~F}$-nucleophilic substitution $\left(\mathrm{S}_{\mathrm{N}} 2\right)$ reaction and to advance the biologic characterization of ${ }^{18} \mathrm{~F}$-FDM for potential application as a tumor-imaging agent. Methods: We synthesized 4,6-O-benzylidene-3-O-ethoxymethyl-1-O-methyl-2-O-trifluoromethanesulfonyl- $\beta$-D-glucopyranoside as a precursor for the nucleophilic synthesis of ${ }^{18} \mathrm{~F}-\mathrm{FDM}$. The precursor was radiofluorinated with ${ }^{18} \mathrm{~F}-\mathrm{KF} / \mathrm{Kryptofix} 222$, followed by removal of the protecting groups with an acid. ${ }^{18} \mathrm{~F}$-FDM was purified by preparative highperformance liquid chromatography and then subjected to in vitro evaluation regarding phosphorylation by hexokinase as well as uptake and metabolism in AH109A tumor cells. The in vivo properties of ${ }^{18} \mathrm{~F}$-FDM were examined in Donryu rats bearing $\mathrm{AH} 109 \mathrm{~A}$ tumor cells by biodistribution studies and imaging with a smallanimal PET system. Results: We radiosynthesized ${ }^{18} \mathrm{~F}-\mathrm{FDM}$ in sufficient radiochemical yields $(50 \%-68 \%)$ with excellent purities (97.6\%-98.7\%). ${ }^{18}$ F-FDM was phosphorylated rapidly by hexokinase, resulting in $98 \%$ conversion into ${ }^{18} \mathrm{~F}-\mathrm{FDG}-6$-phosphate within $30 \mathrm{~min}$. Tumor cells showed significant uptake of ${ }^{18} \mathrm{~F}-\mathrm{FDM}$ with time in vitro, and uptake was dose-dependently inhibited by D-glucose. ${ }^{18} \mathrm{~F}-\mathrm{FDM}$ injected into tumor-bearing rats showed greater uptake in tumors $(2.17 \pm 0.32$ percentage injected dose per gram $[\% / D / g])$ than in the brain $(1.42 \pm 0.10 \% \mathrm{ID} / \mathrm{g})$ at $60 \mathrm{~min}$ after injection. PET studies also revealed the tumor uptake of ${ }^{18} \mathrm{~F}$ FDM (quasi-standardized uptake value, $2.83 \pm 0.22$ ) to be the same as that of ${ }^{18} \mathrm{~F}-\mathrm{FDG}(2.40 \pm 0.30)$, but the brain uptake of ${ }^{18} \mathrm{~F}-\mathrm{FDM}(1.89 \pm 0.13)$ was $\approx 30 \%$ lower than that of ${ }^{18} \mathrm{~F}-\mathrm{FDG}(2.63$ $\pm 0.26)$. Conclusion: We prepared ${ }^{18} \mathrm{~F}-\mathrm{FDM}$ with good radiochemical yield and purity by an $\mathrm{S}_{\mathrm{N}} 2$ reaction. We demonstrated that ${ }^{18} \mathrm{~F}$ FDM had adequate tumor cell uptake by a metabolic trapping mechanism and can afford high-contrast tumor images with less uptake in the brain, indicating that ${ }^{18} \mathrm{~F}$-FDM has almost the same potential as ${ }^{18} \mathrm{~F}-\mathrm{FDG}$ for PET tumor imaging, with better advantages with regard to the imaging of brain tumors.

Received Sep. 23, 2012; revision accepted Feb. 19, 2013.

For correspondence or reprints contact: Shozo Furumoto, 2-1 Seiryomachi, Aoba-ku Sendai 980-8575, Japan.

E-mail: furumoto@cyric.tohoku.ac.jp

Published online Jul. 10, 2013.

COPYRIGHT (C 2013 by the Society of Nuclear Medicine and Molecular Imaging, Inc.
Key Words: ${ }^{18} \mathrm{~F}$-fluorodeoxy mannose; cancer; PET; hexokinase; $\mathrm{S}_{\mathrm{N}} 2$ reaction

J Nucl Med 2013; 54:1354-1361

DOI: 10.2967/jnumed.112.113571

$\mathbf{F}$ luorine-18-labeled 2-deoxy-2-fluoro-D-glucose ( ${ }^{18} \mathrm{~F}-\mathrm{FDG}$, Fig. 1A), a glucose analog, is taken up into tumor cells through membrane transport by glucose transporter 1 (GLUT1), phosphorylated by hexokinase, and then trapped in tissues (1-3). Rapid and high accumulation of ${ }^{18}$ F-FDG in animal tumors was first described by Som et al. (4) and later by Fukuda et al. (5). Several experimental and clinical studies from our research team $(6)$ have been conducted to reveal the usefulness of ${ }^{18} \mathrm{~F}$-FDG PET in cancer imaging. ${ }^{18} \mathrm{~F}-\mathrm{FDG}$ has been used widely as a PET tracer for tumor imaging, and the usefulness of ${ }^{18}$ F-FDG PET in clinical oncology has been well documented (7-9).

2-Deoxy-2- ${ }^{18}$ F-fluoro-D-mannose $\left({ }^{18} \mathrm{~F}-\mathrm{FDM}\right.$; Fig. $\left.1 \mathrm{~B}\right)$ is a derivative of D-mannose and an isomer of ${ }^{18} \mathrm{~F}-\mathrm{FDG}$. Previously, we showed that the uptake of ${ }^{18} \mathrm{~F}-\mathrm{FDM}$ in tumors was as high as that of ${ }^{18} \mathrm{~F}-\mathrm{FDG}$ and that the uptake in the normal brain was $30 \%$ lower than that of ${ }^{18} \mathrm{~F}-\mathrm{FDG}$, with faster blood clearance (5). However, the detailed mechanism of action of ${ }^{18} \mathrm{~F}-\mathrm{FDM}$ uptake in tumors has not been undertaken. Whether ${ }^{18} \mathrm{~F}-\mathrm{FDM}$ can be used as a PET radiopharmaceutical for cancer imaging, with results almost comparable or superior to ${ }^{18} \mathrm{~F}-\mathrm{FDG}$, has not been elucidated. With regard to use as a tumor-imaging agent, lower uptake in the normal brain is an attractive property of ${ }^{18} \mathrm{~F}-\mathrm{FDM}$ and could be a potential application for brain tumor imaging by ${ }^{18} \mathrm{~F}-\mathrm{FDM}$ PET. Additionally, it is also of interest whether ${ }^{18} \mathrm{~F}$ FDM shows uptake in the same manner as ${ }^{18} \mathrm{~F}-\mathrm{FDG}$ in inflamed tissue.

To conduct further studies on ${ }^{18} \mathrm{~F}-\mathrm{FDM}$, however, the establishment of a practical synthetic method is necessary. Classically, ${ }^{18} \mathrm{~F}$-FDM has been obtained as a by-product of ${ }^{18} \mathrm{~F}$-FDG synthesis by electrophilic fluorination (10). Today, nucleophilic displacement reactions are used in the large-scale synthesis of ${ }^{18} \mathrm{~F}-\mathrm{FDG}$ from protected mannose analogs that have a triflate group as a leaving group (11). This approach also seems to be applicable for the large-scale synthesis of ${ }^{18} \mathrm{~F}$-FDM. Actually, ${ }^{18} \mathrm{~F}-\mathrm{FDM}$ had been synthesized from a glucose triflate protected with stable protecting groups by an $\mathrm{S}_{\mathrm{N}} 2\left({ }^{18} \mathrm{~F}-\right.$ nucleophilic substitution) reaction with ${ }^{18} \mathrm{~F}$-fluoride in good yields $(12,13)$, but the method 


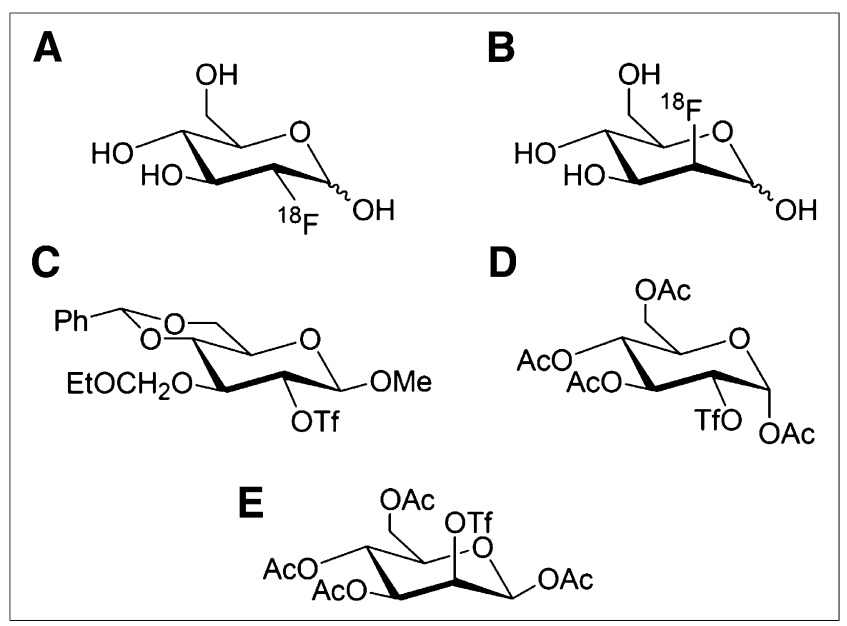

FIGURE 1. Chemical structures: ${ }^{18} \mathrm{~F}-\mathrm{FDG}(\mathrm{A}),{ }^{18} \mathrm{~F}-\mathrm{FDM}(\mathrm{B})$, precursor-1 for ${ }^{18} \mathrm{~F}-\mathrm{FDM}$ synthesis (C), precursor-2 for ${ }^{18} \mathrm{~F}-\mathrm{FDM}$ synthesis $(\mathrm{D})$, and precursor for ${ }^{18} \mathrm{~F}-\mathrm{FDG}$ synthesis $(\mathrm{E})$.

requires hydrolysis by a strong acid at high temperature for deprotection after fluorination.

In the present study, we prepared a new precursor for ${ }^{18} \mathrm{~F}$ FDM that can be radiolabeled by an $\mathrm{S}_{\mathrm{N}} 2$ reaction and optimized the conditions and procedure of radiosynthesis. We then used it for evaluation of in vitro uptake and metabolism in tumor cells, in vivo biodistribution, and PET imaging using tumor- and inflammation-bearing rats to revalidate the utility of ${ }^{18} \mathrm{~F}$-FDM for cancer imaging.

\section{MATERIALS AND METHODS}

\section{Precursors for ${ }^{18}$ F-FDM Synthesis}

${ }^{18} \mathrm{~F}-\mathrm{FDM}$ radiosynthesis was undertaken using 2 types of precursor: 4,6-O-benzylidene-3-O-ethoxymethyl-2- $O$-trifluoromethanesulfonyl1- $O$-methyl- $\beta$-D-glucopyranoside (precursor-1; Fig. $1 \mathrm{C}$ ) and 1,3,4,6tetra- $O$-acetyl-2- $O$-trifluoromethanesulfonyl- $\alpha$-D-glucopyranoside (precursor-2; Fig. 1D). Precursor-2 was prepared according to the literature (14). Precursor-1 was synthesized by trifluoromethanesulfonylation of the 2-hydroxyl group of 4,6- $O$-benzylidene-3- $O$ ethoxymethyl-1- $O$-methyl- $\beta$-D-glucopyranoside (15). The structure was determined by electrospray ionization mass spectroscopy and nuclear MR spectroscopy. Mass spectra were obtained on a JMS-DX303 system (JEOL). ${ }^{1} \mathrm{H}-\mathrm{NMR}$ (nuclear magnetic resonance) and ${ }^{13} \mathrm{C}$ NMR spectra were recorded on an Avance III 600 system (Bruker). For precise assignment, the spectra of gradient-selected heteronuclear multiple-bond correlation and pulse gradient-selected heteronuclear multiple-quantum correlation were also recorded. MS m/z: 339.1 $[\mathrm{M}+\mathrm{H}]^{+} .{ }^{1} \mathrm{H}-\mathrm{NMR}\left(600 \mathrm{MHz}, \mathrm{CDCl}_{3}\right) \delta 1.21(3 \mathrm{H}, \mathrm{m}), 3.44-3.51$ $(3 \mathrm{H}, \mathrm{m}), 3.60(4 \mathrm{H}, \mathrm{m}), 3.69(1 \mathrm{H}, \mathrm{t}, 9.0 \mathrm{~Hz}), 3.77-3.83(3 \mathrm{H}, \mathrm{m}), 3.95$ $(1 \mathrm{H}, \mathrm{d}, 1.2 \mathrm{~Hz}), 4.35-4.39(2 \mathrm{H}, \mathrm{m}), 4.81(1 \mathrm{H}, \mathrm{d}, 7.2 \mathrm{~Hz}), 4.92(1 \mathrm{H}, \mathrm{d}$, $6.6 \mathrm{~Hz}), 5.54(1 \mathrm{H}, \mathrm{s}), 7.35-7.49(5 \mathrm{H}, \mathrm{m}),{ }^{13} \mathrm{C}-\mathrm{NMR}(150 \mathrm{MHz}$, $\left.\mathrm{CDCl}_{3}\right) \delta 14.8,57.5,64.2,66.4,69.7,74.0,79.6,82.0,96.5,101.6$, 104.4, 126.1, 126.2, 128.2, 129.1, 137.1.

\section{Radiosynthesis}

No-carrier-added ${ }^{18} \mathrm{~F}$-fluoride was produced by the ${ }^{18} \mathrm{O}(\mathrm{p}, \mathrm{n}){ }^{18} \mathrm{~F}$ reaction on enriched ${ }^{18} \mathrm{O}-\mathrm{H}_{2} \mathrm{O}$ (Taiyo Nippon Sanso) with an HM12 cyclotron (Sumitomo Heavy Industries) installed in the Cyclotron and Radioisotope Center (CYRIC) of Tohoku University. The specific activity (SA) of ${ }^{18} \mathrm{~F}$-fluoride was in the range of $74-740 \mathrm{GBq} / \mu \mathrm{mol}$ at the end of bombardment.

Radiofluorination using the ${ }^{18} \mathrm{~F}$-fluoride and precursor- 1 and precursor- 2 was performed by a conventional $\mathrm{S}_{\mathrm{N}} 2$ reaction with activated ${ }^{18} \mathrm{~F}-\mathrm{KF} / \mathrm{Kryptofix} 222(16,17)$. Briefly, the aqueous ${ }^{18} \mathrm{~F}^{-}$contained in the $\mathrm{K}_{2} \mathrm{CO}_{3}$ solution (1.88-3.47 GBq) and Kryptofix 222 $(15 \mathrm{mg})$ were placed in a brown vial. Then, water was removed by azeotropic means with acetonitrile by heating at $110^{\circ} \mathrm{C}$ and helium gas flow. After drying, the activated ${ }^{18} \mathrm{~F}-\mathrm{KF} / \mathrm{Kryptofix} 222$ was reacted with the precursor in $\mathrm{CH}_{3} \mathrm{CN}(1.0 \mathrm{~mL})$ at $110^{\circ} \mathrm{C}$ (sealed condition) for $10 \mathrm{~min}$. $\mathrm{CH}_{3} \mathrm{CN}$ was then removed by helium gas flow. Deprotection of the hydroxyl groups was undertaken by the addition of aqueous $6 \mathrm{M} \mathrm{HCl}$, followed by a 20 -min reaction at $110^{\circ} \mathrm{C}$. The crude product was neutralized with $4 \mathrm{M} \mathrm{NaOH}$ and $400 \mathrm{mM} \mathrm{Na} \mathrm{HPO}_{4}$ and then subjected to semipreparative high-performance liquid chromatography (HPLC; column: YMC Pack ODS-A, $250 \times 20 \mathrm{~mm}, 5 \mu \mathrm{m}$ [YMC Co. Ltd.]; mobile phase: $0.9 \%$ aqueous $\mathrm{NaCl}$; flow rate: $6.0 \mathrm{~mL} / \mathrm{min}) .{ }^{18} \mathrm{~F}$ FDG prepared by a conventional method (11) for a clinical ${ }^{18} \mathrm{~F}-\mathrm{FDG}$ PET study at the CYRIC was used for biologic experiments without further purification by HPLC.

Radiochemical purities were determined by radio-thin-layer chromatography (radio-TLC) on silica gel aluminum sheets impregnated with monosodium phosphate $\left(60 \mathrm{~F}_{254}\right.$; Merck) with $\mathrm{CH}_{3} \mathrm{CN} / \mathrm{H}_{2} \mathrm{O}, 95 / 5$ $(v / v)$ as eluent. The development process to separate ${ }^{18} \mathrm{~F}-\mathrm{FDG}$ and ${ }^{18} \mathrm{~F}-\mathrm{FDM}$ was performed according to the literature (18). After development, the plate was dried and exposed to a BAS imaging plate (Fuji Film). Autoradiograms of radio-TLC were obtained using a BAS-5000 phosphor imaging instrument (Fuji Film).

TABLE 1

Reaction Conditions and Yields for ${ }^{18} \mathrm{~F}-\mathrm{FDM}$ Synthesis from Precusor-1

\begin{tabular}{|c|c|c|c|c|c|c|c|}
\hline \multicolumn{2}{|c|}{ Precursor-1 } & \multirow[b]{2}{*}{$\mathrm{K}_{2} \mathrm{CO}_{3}(\mu \mathrm{mol})$} & \multirow[b]{2}{*}{${ }^{18} \mathrm{~F}(\mathrm{GBq})$} & \multirow[b]{2}{*}{${ }^{18} \mathrm{~F}$-fluorination time $(\mathrm{min})^{\star}$} & \multicolumn{2}{|c|}{ Deprotection* } & \multirow[b]{2}{*}{ Yield $(\%)^{\dagger}$} \\
\hline $\mathrm{mg}$ & $\mu \mathrm{mol}$ & & & & Acid & Time (min) & \\
\hline 5.0 & 11 & 14.4 & 2.30 & 30 & $5 \mathrm{M} \mathrm{HCl}, 1.0 \mathrm{~mL}$ & 30 & 70 \\
\hline 5.0 & 11 & 9.9 & 2.00 & 30 & $5 \mathrm{M} \mathrm{HCl}, 1.5 \mathrm{~mL}$ & 30 & 64 \\
\hline 3.0 & 6.4 & 14.4 & 3.44 & 30 & $6 \mathrm{M} \mathrm{HCl}, 1.0 \mathrm{~mL}$ & 30 & 68 \\
\hline 3.0 & 6.4 & 6.6 & 3.47 & 30 & $6 \mathrm{M} \mathrm{HCl}, 1.0 \mathrm{~mL}$ & 30 & 50 \\
\hline 3.0 & 6.4 & 16.5 & 1.88 & 10 & $6 \mathrm{M} \mathrm{HCl}, 1.0 \mathrm{~mL}$ & 20 & 60 \\
\hline 3.0 & 6.4 & 6.6 & 2.44 & 10 & $6 \mathrm{M} \mathrm{HCl}, 1.0 \mathrm{~mL}$ & 10 & 43 \\
\hline
\end{tabular}

${ }^{*}$ Fluorination and deprotection were performed at $110^{\circ} \mathrm{C}$.

${ }^{\dagger}$ Decay-corrected radiochemical yield.

Acetonitrile (reaction solvent) was not removed by evaporation after fluorination. 


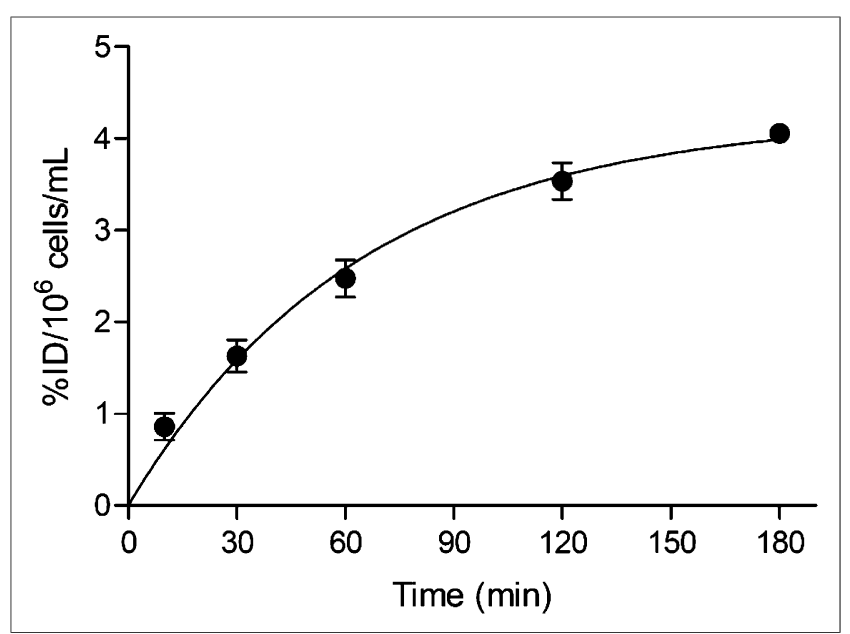

FIGURE 2. In vitro uptake of ${ }^{18} \mathrm{~F}-\mathrm{FDM}$ into $\mathrm{AH} 109 \mathrm{~A}$ cells.

\section{Uptake of ${ }^{18}$ F-FDM into Tumor Cells In Vitro}

Nonadherent rat hepatoma cells AH109A (19) were cultured with RPMI-1640 medium containing L-glutamine and D-glucose (Wako Chemical Industries) and used for uptake studies $\left(1.5-1.9 \times 10^{6}\right.$ cells $/ \mathrm{mL}$ of medium). The medium was replaced with D-glucose-free RPMI-1640 medium (Gibco) 3-4 h before experimentation.

${ }^{18} \mathrm{~F}-\mathrm{FDM}$ in saline $(100 \mu \mathrm{L} ; 1.29 \mathrm{MBq} / \mathrm{mL}$ at start of experimentation; radiochemical purity, $>96 \%$ ) was added to a 96-well plate. Suspended AH109A cells in $100 \mu \mathrm{L}$ of D-glucose-free RPMI-1640 medium at a final density of $0.75 \times 10^{6}$ cells $/ \mathrm{mL}$ were added to the wells and incubated at $37^{\circ} \mathrm{C}$ with continuous stirring. Cells were harvested at predetermined times through suction filtration with a vacuum manifold (Millipore) at 20,60, 120, and $180 \mathrm{~min}$. Trapped cells were washed three times with phosphate-buffered saline (200 $\mu \mathrm{L} /$ well). Filters holding the trapped cells were then separated, and radioactivity was measured with a $\gamma$-counter (AccuFLEX $\gamma 7000$; Hitachi Aloka Medical). The radioactivity of ${ }^{18} \mathrm{~F}-\mathrm{FDM}$ in tumor cells was expressed as percentage injected dose per $10^{6}$ cells (\% ID/106 cells).

\section{Uptake into Tumor Cells Under D-glucose Load}

${ }^{18} \mathrm{~F}-\mathrm{FDM}$ or ${ }^{18} \mathrm{~F}-\mathrm{FDG}$ in $50 \mu \mathrm{L}$ of saline $(1.38 \mathrm{MBq} / \mathrm{mL}$ at the start of experimentation; radiochemical purity, $>96 \%$ ) was mixed with

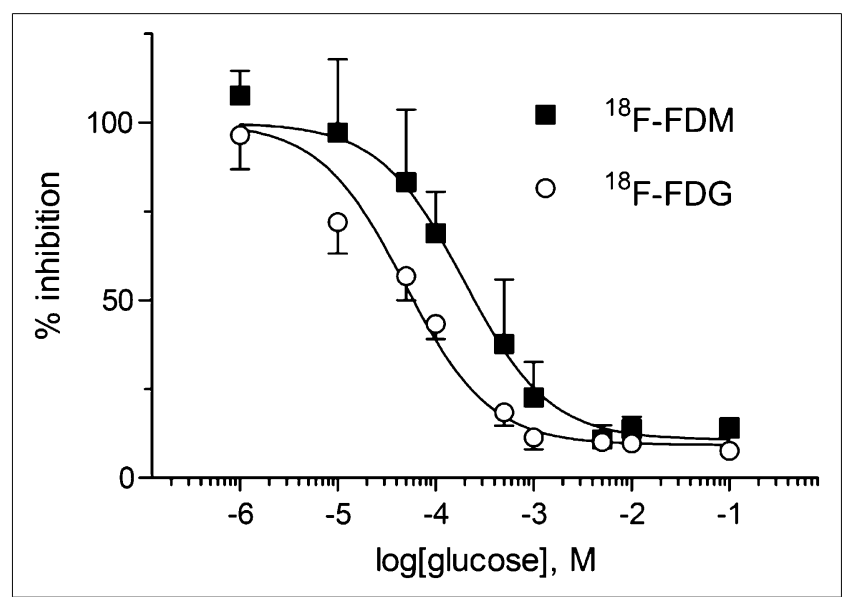

FIGURE 3. Inhibition of uptake of tracers in tumor cells by D-glucose. $I C_{50}$ values due to inhibition by $\mathrm{D}$-glucose were 1.95 $\times 10^{-1} \mathrm{mM}$ for ${ }^{18} \mathrm{~F}-\mathrm{FDM}$ and $4.47 \times 10^{-2} \mathrm{mM}$ for ${ }^{18} \mathrm{~F}-\mathrm{FDG}$.

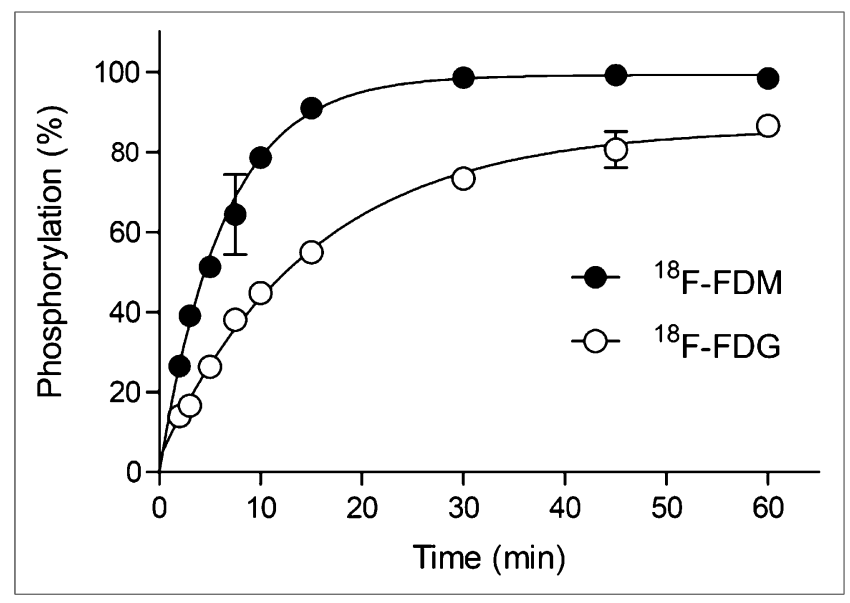

FIGURE 4. Phosphorylation of ${ }^{18} \mathrm{~F}-\mathrm{FDM}$ and ${ }^{18} \mathrm{~F}-\mathrm{FDG}$ by yeast hexokinase. Percentages of 6-phosphorylation versus incubation time are shown. ${ }^{18} \mathrm{~F}$-FDM showed more rapid 6-phosphorylation than ${ }^{18} \mathrm{~F}-\mathrm{FDG}$.

D-glucose in $50 \mu \mathrm{L}$ of medium at a final concentration of $0,0.1$, 1.0, 5.0, and $10 \mathrm{mM}$ and put into a 96-well plate. Then, $100 \mu \mathrm{L}$ of AH109A cells suspended in D-glucose-free RPMI-1640 medium at a density of $0.95 \times 10^{6}$ cells $/ \mathrm{mL}$ were added to the wells and incubated at $37^{\circ} \mathrm{C}$ for $2 \mathrm{~h}$ with continuous stirring. Tumor cells were trapped and washed, and the radioactivity was measured as described above. Half-maximal inhibitory concentration $\left(\mathrm{IC}_{50}\right)$ values for the uptake inhibition by D-glucose were calculated by fitting the data to a sigmoidal dose-response regression curve with GraphPad Prism software (version 5.0; GraphPad Software).

\section{Metabolism Studies}

Enzymatic phosphorylation of ${ }^{18} \mathrm{~F}-\mathrm{FDM}$ and ${ }^{18} \mathrm{~F}-\mathrm{FDG}$ was examined with yeast hexokinase (Saccharomyces cerevisiae; SigmaAldrich). Seventy-four kilobecquerels of ${ }^{18} \mathrm{~F}-\mathrm{FDM}$ or ${ }^{18} \mathrm{~F}-\mathrm{FDG}$ (in $10 \mu \mathrm{L}$ of saline) were added to a mixture of yeast hexokinase $(8 \mu \mathrm{L}, 100 \mathrm{U} / \mathrm{mL})$, adenosine triphosphate $(40 \mu \mathrm{L}, 40 \mu \mathrm{M}), \mathrm{MgCl}_{2}$ (20 $\mu \mathrm{L}, 170 \mathrm{mM}$ ), and Tris-buffered phosphate-buffered saline (102 $\mu \mathrm{L})$ and incubated at $37^{\circ} \mathrm{C}$. The enzymatic reaction was stopped by the addition of aqueous $\mathrm{HClO}_{4}(100 \mu \mathrm{L}, 1.0 \mathrm{M})$ at 2, 3, 5, 7.5, 30, and $60 \mathrm{~min}$ after the start of incubation. The solution was neutralized and used for analyses by radio-TLC on silica gel-coated aluminum sheets $\left(60 \mathrm{~F}_{254}\right.$; Merck) with ethanol/AcNH $4(1 \mathrm{M}), 1: 1(v / v)$ as eluent. After development, autoradiograms of radio-TLC were obtained by the method as described above.

To examine metabolism in tumor cells, $74 \mathrm{kBq}$ of ${ }^{18} \mathrm{~F}-\mathrm{FDM}$ (in $50 \mu \mathrm{L}$ of saline) were added to AH109A cells $\left(100 \mu \mathrm{L}, 0.75 \times 10^{6}\right.$ cells $/ \mathrm{mL}$ ) and incubated at $37^{\circ} \mathrm{C}$. Cells were harvested by centrifugation $\left(500 \mathrm{~g}, 5 \mathrm{~min}, 4^{\circ} \mathrm{C}\right) 10,60$, and $120 \mathrm{~min}$ after incubation. Their radioactivities were measured by a $\gamma$-counter. Metabolites were extracted by $50 \%$ ethanol and analyzed by radio-TLC as described above.

\section{Biodistribution Study of ${ }^{18}$ F-FDM}

The Ethics Committee for Experimental Research in Animals of Tohoku University approved the study protocol. AH109A cells (which were maintained in ascites form in Donryu rats) were used for preparing tumor-bearing rats. Tumor cells in ascites $\left(5 \times 10^{5}\right.$ cells $)$ were inoculated subcutaneously into the right flank of Donryu rats. After $9 \mathrm{~d}$, by which time the tumor had grown to $\approx 1-2 \mathrm{~cm}$ in diameter, ${ }^{18} \mathrm{~F}$-FDM in saline $(1.11 \mathrm{MBq} / 300 \mu \mathrm{L})$ was injected into the lateral tail vein. Rats were killed by cervical dislocation after heart puncture to obtain blood samples 60 and 120 min after injection (5 rats at each time point). Tumors and organs were removed shortly thereafter 


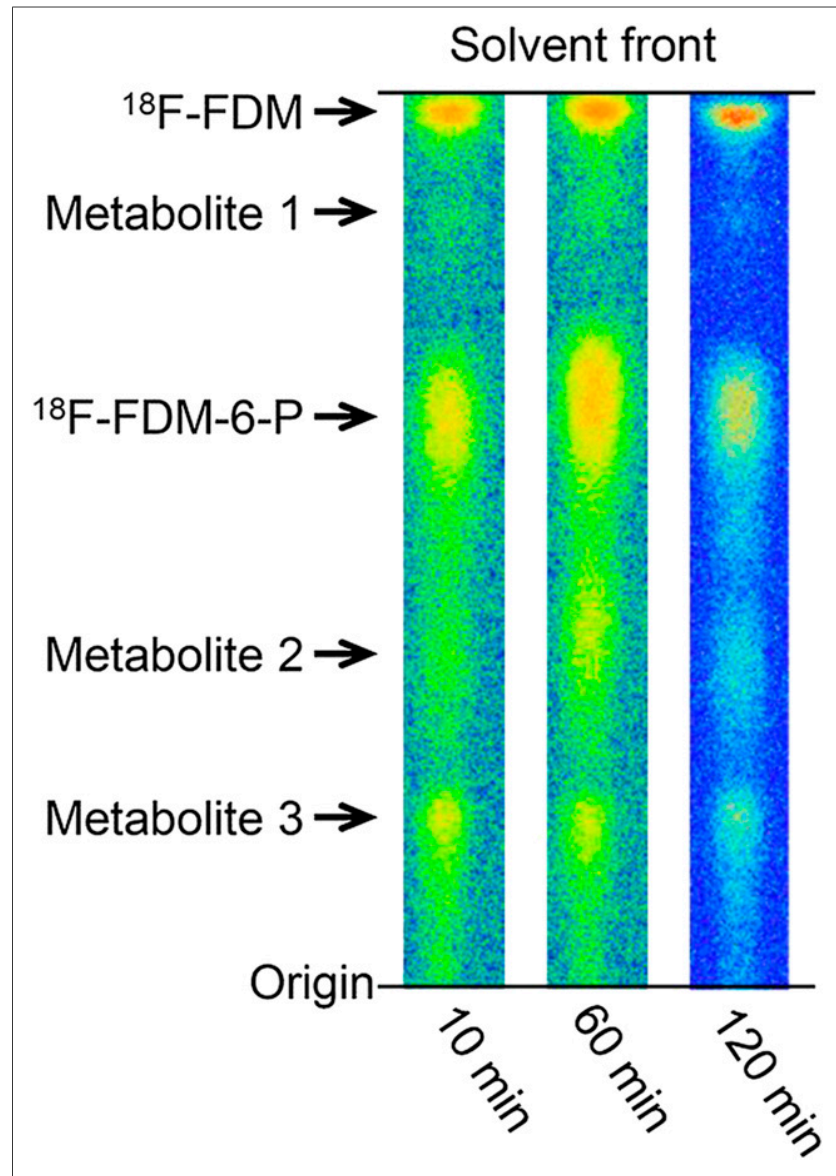

FIGURE 5. Radio-TLC autoradiograms of ${ }^{18} \mathrm{~F}-\mathrm{FDM}$ metabolites obtained 10,60, and 120 min after incubation with AH109A tumor cells in vitro.

and weighed. Radioactivity was measured using a $\gamma$-counter. Tissue uptake was expressed as percentage injected dose per gram of tissue $(\% \mathrm{ID} / \mathrm{g})$.

\section{PET of Tumor- and Inflammation-Bearing Rats}

AH109A cells $\left(5 \times 10^{6}\right.$ cells $)$ were inoculated in the right flank of male Donryu rats (225-268 g). Two or $3 \mathrm{~d}$ after cell inoculation, 200 $\mu \mathrm{L}$ of telepine oil were injected into the left flank. After 7-9 d, by which time the tumor had grown to a diameter of $\approx 2-3 \mathrm{~cm}$, rats were anesthetized with $2 \%$ isoflurane (flow rate, $2 \mathrm{~mL} / \mathrm{min}$ ) at $4 \mathrm{~min}$ before PET. Rats were starved overnight before PET. Whole-body PET of rats was undertaken using a small-animal PET imaging system with a spatial resolution of $1.5 \mathrm{~mm}$ (Clarivivo-PET; Shimadzu) (20). Acquired data were decay-corrected and images reconstructed using the 3-dimensional dynamic row-action maximum likelihood algorithm. Attenuation correction was not performed. After PET, rats were placed onto an animal bed and moved to an animal CT scanner (Clarivivo-CT; Shimadzu). CT images were taken under the same geometry as that used for PET. The next day, PET with ${ }^{18} \mathrm{~F}-\mathrm{FDG}$ was undertaken using the same rats. Three rats were used for the PET study.

We calculated tissue radioactivity per voxel divided by injected activity per body weight of the animals to be used as a parameter of tissue uptake. We expressed it as quasi-standardized uptake value (qSUV) because attenuation correction was not applied for the data.

\section{Statistical Analysis}

The statistical significance of differences in the mean values of qSUV between ${ }^{18} \mathrm{~F}-\mathrm{FDM}$ and ${ }^{18} \mathrm{~F}-\mathrm{FDG}$ was determined using the Student $t$ test. A $P$ value of less than 0.05 was considered significant.

\section{RESULTS}

\section{${ }^{18}$ F-FDM Radiosynthesis}

The reaction conditions and results of ${ }^{18} \mathrm{~F}-\mathrm{FDM}$ synthesis using precursor-1 are summarized in Table 1. With respect to the reaction time, ${ }^{18} \mathrm{~F}$-fluorination for $10-30 \mathrm{~min}$ and deprotection for $20-30 \mathrm{~min}$ afforded ${ }^{18} \mathrm{~F}-\mathrm{FDM}$ in good-to-excellent radiochemical yields $(50 \%-68 \%)$, with sufficient radiochemical purities (97.6\%-98.7\%). An epimerized product, ${ }^{18} \mathrm{~F}-\mathrm{FDG}$, was not found in the final solution of ${ }^{18} \mathrm{~F}-\mathrm{FDM}$. When precursor-2 was used for ${ }^{18} \mathrm{~F}-\mathrm{FDM}$ synthesis, the yields were less than $1 \%$. The SA of ${ }^{18} \mathrm{~F}-\mathrm{FDM}$ (which was not measured in the present study) was estimated to be greater than $37 \mathrm{GBq} / \mu \mathrm{mol}$ (end of synthesis) because no-carrier-added ${ }^{18} \mathrm{~F}$-fluoride $(>74$ $\mathrm{GBq} / \mu \mathrm{mol}$ ) was used and the total synthesis time was less than $110 \mathrm{~min}$.

\section{Uptake of Tracers into Tumor Cells In Vitro}

Uptake of ${ }^{18} \mathrm{~F}-\mathrm{FDM}$ into tumor cells increased with increasing uptake time and reached $44 \% \mathrm{ID} / 10^{6}$ cells $180 \mathrm{~min}$ after the start of incubation (Fig. 2). Although we did not confirm the time for reaching a plateau for uptake, we adopted $120 \mathrm{~min}$ as the incubation time for the following uptake study according to the amount of D-glucose. Figure 3 illustrates the inhibition of ${ }^{18} \mathrm{~F}$ FDM or ${ }^{18}$ F-FDM by D-glucose load. Uptake of either tracer was inhibited dose-dependently by the D-glucose load. The $\mathrm{IC}_{50}$ values by D-glucose were $1.95 \times 10^{-1} \mathrm{mM}$ for ${ }^{18} \mathrm{~F}-\mathrm{FDM}$ and $4.47 \times$ $10^{-2} \mathrm{mM}$ for ${ }^{18} \mathrm{~F}-\mathrm{FDG}$.

\section{Metabolism in AH109A Tumor Cells}

After incubation of ${ }^{18} \mathrm{~F}-\mathrm{FDG}$ with yeast hexokinase, a metabolite showing a retention factor (Rf) value of 0.63 , ${ }^{18} \mathrm{~F}-\mathrm{FDG}-6-$

TABLE 2

Metabolism of ${ }^{18} \mathrm{~F}-\mathrm{FDM}$ in AH109A Tumor Cells

\begin{tabular}{lcrrr}
\hline Metabolites of ${ }^{18}$ F-FDM (\%) & Rf & $10 \min$ & $60 \min$ & 120 min \\
\hline 18F-FDM & 0.97 & $26.2 \pm 3.2$ & $23.2 \pm 2.1$ & $23.6 \pm 5.4$ \\
Metabolite 1 & 0.86 & $1.5 \pm 0.4$ & $1.3 \pm 0.8$ & $9.7 \pm 3.6$ \\
18F-FDM-6-P & 0.65 & $43.4 \pm 1.6$ & $48.2 \pm 0.8$ & $41.0 \pm 2.7$ \\
Metabolite 2 & 0.38 & $8.3 \pm 4.0$ & $17.0 \pm 1.6$ & $1.7 \pm 0.3$ \\
Metabolite 3 & 0.21 & $20.6 \pm 4.7$ & $10.3 \pm 0.4$ & $24.0 \pm 1.3$ \\
\hline
\end{tabular}

Data are mean $\pm \operatorname{SD}(n=3-4)$ 
TABLE 3

Biodistribution of ${ }^{18} \mathrm{~F}-\mathrm{FDM}$ in AH109A Tumor Cell-Bearing Donryu Rats

\begin{tabular}{|c|c|c|c|c|}
\hline \multirow[b]{2}{*}{ Organ } & \multicolumn{2}{|c|}{ Uptake (\%ID/g) } & \multicolumn{2}{|c|}{ Tumor-to-organ ratio } \\
\hline & $60 \min$ & $120 \mathrm{~min}$ & $60 \mathrm{~min}$ & $120 \mathrm{~min}$ \\
\hline Blood & $0.11 \pm 0.02$ & $0.06 \pm 0.01$ & $19.7 \pm 1.7$ & $36.9 \pm 3.7$ \\
\hline Heart & $0.46 \pm 0.25$ & $0.75 \pm 0.22$ & $6.5 \pm 4.5$ & $2.9 \pm 0.8$ \\
\hline Lung & $0.37 \pm 0.04$ & $0.41 \pm 0.06$ & $5.8 \pm 0.6$ & $5.1 \pm 0.7$ \\
\hline Liver & $0.21 \pm 0.03$ & $0.14 \pm 0.02$ & $10.3 \pm 0.8$ & $14.7 \pm 1.6$ \\
\hline Kidney & $0.53 \pm 0.05$ & $0.58 \pm 0.01$ & $4.1 \pm 0.3$ & $3.6 \pm 0.3$ \\
\hline Spleen & $0.36 \pm 0.04$ & $0.24 \pm 0.03$ & $6.0 \pm 0.5$ & $8.9 \pm 1.0$ \\
\hline Stomach & $0.45 \pm 0.13$ & $0.42 \pm 0.10$ & $5.0 \pm 0.9$ & $5.1 \pm 0.8$ \\
\hline Small intestine & $0.58 \pm 0.24$ & $0.61 \pm 0.05$ & $10.2 \pm 12.9$ & $3.4 \pm 0.3$ \\
\hline Muscle (femur) & $0.12 \pm 0.04$ & $0.15 \pm 0.02$ & $21.2 \pm 8.2$ & $14.4 \pm 2.6$ \\
\hline Bone (femur) & $0.36 \pm 0.05$ & $0.41 \pm 0.05$ & $6.2 \pm 1.7$ & $5.1 \pm 0.5$ \\
\hline Brain & $1.42 \pm 0.10$ & $1.32 \pm 0.14$ & $1.4 \pm 0.2$ & $1.6 \pm 0.1$ \\
\hline Tumor & $2.17 \pm 0.32$ & $2.09 \pm 0.20$ & $1.0 \pm 0.0$ & $1.0 \pm 0.0$ \\
\hline
\end{tabular}

Data are mean $\pm \operatorname{SD}(n=4)$.

phosphate $\left({ }^{18} \mathrm{~F}-\mathrm{FDG}-6-\mathrm{P}\right)$, was observed. The fraction of ${ }^{18} \mathrm{~F}-$ FDG-6-P increased with time and almost reached a plateau at 60 min (Fig. 4). In the case of ${ }^{18}$ F-FDM, a metabolite showing an $\mathrm{Rf}$ value of 0.63 was identified and considered to be ${ }^{18} \mathrm{~F}-\mathrm{FDM}-$ 6-P because FDM is known to be a good substrate for hexokinase (2). The fraction of ${ }^{18} \mathrm{~F}-\mathrm{FDM}-6-\mathrm{P}$ increased with a faster initial speed than that by ${ }^{18} \mathrm{~F}-\mathrm{FDG}$ and reached a plateau at 30 min (Fig. 4).

Figure 5 shows the profiles of metabolites analyzed by radioTLC 10, 60, and $120 \mathrm{~min}$ after incubation with AH109A cells and ${ }^{18} \mathrm{~F}$-FDM. In addition to ${ }^{18} \mathrm{~F}$-FDM, 4 metabolites were observed. The Rf value of the major metabolite was 0.62 and coincided with the Rf value of the metabolite produced by hexokinase. Therefore, the metabolite was considered to be ${ }^{18}$ F-FDM-6-P. The fraction of this metabolite reached $43.4 \%$ at $10 \mathrm{~min}$ and remained constant until $120 \mathrm{~min}(41.0 \%)$ (Table 2). The other 3 metabolites were not identified.
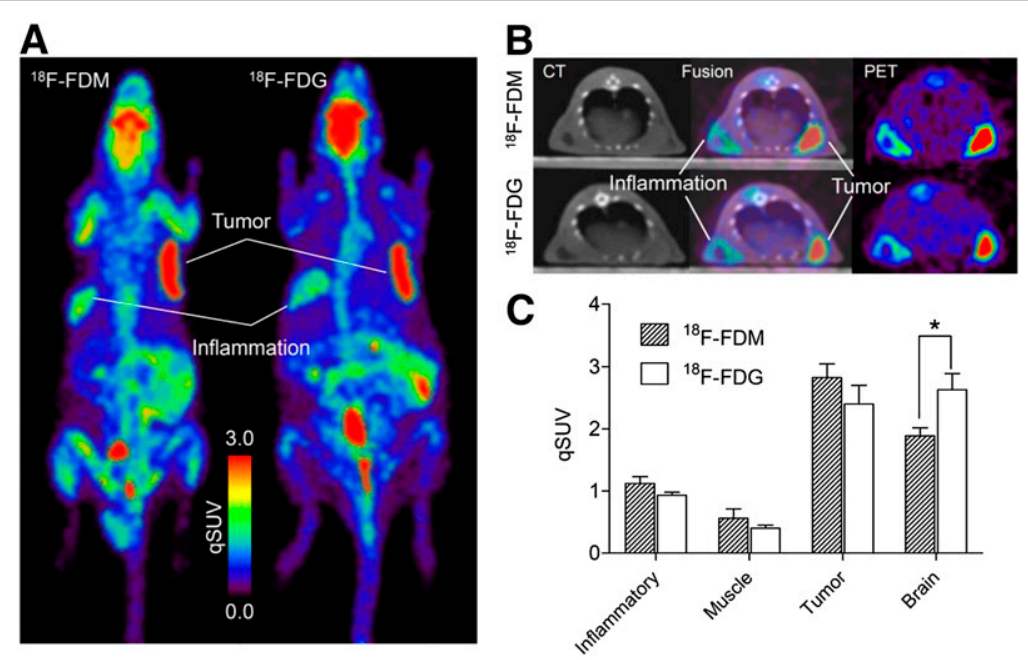

FIGURE 6. PET images of tumor- and inflammation-bearing rats and comparison with qSUVs. (A) Representative maximum-intensity-projection images of ${ }^{18} \mathrm{~F}-\mathrm{FDM}$ and ${ }^{18} \mathrm{~F}-$ FDG. (B) Representative transaxial PET and CT images of rats. (C) Tissue uptake (qSUV) of ${ }^{18} \mathrm{~F}-\mathrm{FDM}$ and ${ }^{18} \mathrm{~F}-\mathrm{FDG}\left(n=3,{ }^{*} P<0.05\right)$.

\section{Biodistribution Study}

Table 3 illustrates the result of the biodistribution study. The tumor uptake of ${ }^{18} \mathrm{~F}-\mathrm{FDM}$ was the highest among the tissues: $2.17 \pm 0.32$ and $2.09 \pm 0.20 \% \mathrm{ID} / \mathrm{g}$ at 60 and $120 \mathrm{~min}$, respectively. Relatively high uptake was observed in the brain $(1.42 \pm$ $0.10 \% \mathrm{ID} / \mathrm{g}$ ) at $60 \mathrm{~min}$. Uptake in the other normal organs was less than $0.6 \% \mathrm{ID} / \mathrm{g}$ at $60 \mathrm{~min}$ after injection. Levels in the blood were low $(0.11 \pm 0.02$ and $0.06 \pm 0.01 \% \mathrm{ID} / \mathrm{g}$ at 60 and $120 \mathrm{~min}$, respectively). The tumor-to-blood and tumor-to-muscle ratios were 19.0 and 18.8 , respectively, at $60 \mathrm{~min}$ after injection. The tumor-to-brain ratio was 1.5 and 1.6 at 60 and $120 \mathrm{~min}$ after injection, respectively.

\section{PET of Tumor- and Inflammation-Bearing Rats}

The results of PET of Donryu rats with tumors and inflammation at $55-65 \mathrm{~min}$ after the injection of ${ }^{18} \mathrm{~F}-\mathrm{FDM}$ and ${ }^{18} \mathrm{~F}-\mathrm{FDG}$ are summarized in Figure 6. Tumors were visualized clearly in maximum-intensity-projection images, with fewer counts in the inflammation model with ${ }^{18} \mathrm{~F}-\mathrm{FDM}$ or ${ }^{18} \mathrm{~F}$-FDG (Fig. $6 \mathrm{~A})$. Uptake of ${ }^{18} \mathrm{~F}-\mathrm{FDM}$ in the brain was less than that of ${ }^{18}$ F-FDG. Transaxial images also demonstrated high uptake in tumors, whereas relatively low uptake in inflammatory tissue with a central lowcount area was noted (Fig. 6B). qSUVs in tumors and tissues are shown in Figure $6 \mathrm{C}$ and Table 4. Tumor uptake of ${ }^{18} \mathrm{~F}$ FDM and ${ }^{18}$ F-FDG by qSUV was $2.83 \pm$ 0.22 and $2.40 \pm 0.30$, respectively, with no significant differences between the 2 values. Uptake of ${ }^{18} \mathrm{~F}-\mathrm{FDM}$ in the brain $(1.89 \pm 0.13)$ was significantly $(P<$ $0.05)$ lower than that of ${ }^{18}$ F-FDG $(2.63 \pm$ 0.26 ). Uptake in chemically induced inflammatory tissues was $1.12 \pm 0.11$ and $0.93 \pm 0.03$ in ${ }^{18} \mathrm{~F}-\mathrm{FDM}$ and ${ }^{18} \mathrm{~F}-\mathrm{FDG}$, respectively. These values were less than half those of tumor uptake, and there was no significant difference between the 2 
TABLE 4

Uptake of ${ }^{18} \mathrm{~F}-\mathrm{FDM}$ and ${ }^{18} \mathrm{~F}-\mathrm{FDG}$ into Tissues and Tumors as Measured by PET

\begin{tabular}{|c|c|c|c|c|}
\hline \multirow[b]{2}{*}{ Organ } & \multicolumn{2}{|c|}{${ }^{18} \mathrm{~F}-\mathrm{FDM}$} & \multicolumn{2}{|c|}{${ }^{18} \mathrm{~F}-\mathrm{FDG}$} \\
\hline & qSUV* & Ratio $^{\dagger}$ & qSUV* & Ratio $^{\dagger}$ \\
\hline Inflammatory & $1.12 \pm 0.11$ & $2.07 \pm 0.51$ & $0.93 \pm 0.03$ & $2.38 \pm 0.35$ \\
\hline Muscle & $0.56 \pm 0.15$ & $1.00 \pm 0.00$ & $0.40 \pm 0.05$ & $1.00 \pm 0.00$ \\
\hline Tumor & $2.83 \pm 0.22$ & $5.30 \pm 1.54$ & $2.40 \pm 0.30$ & $6.20 \pm 1.63$ \\
\hline Brain & $1.89 \pm 0.13$ & $3.56 \pm 1.18$ & $2.63 \pm 0.26$ & $6.72 \pm 1.17$ \\
\hline \multicolumn{5}{|c|}{$\begin{array}{l}{ }^{*} \text { Data are mean } \pm \mathrm{SD}(n=3) \\
{ }^{\dagger} \text { Tissue-to-muscle ratio. }\end{array}$} \\
\hline
\end{tabular}

tracers. There was no significant difference between inflammationto-muscle ratios for ${ }^{18} \mathrm{~F}-\mathrm{FDM}$ (2.00) and ${ }^{18} \mathrm{~F}-\mathrm{FDG}$ (2.33).

\section{DISCUSSION}

When one considers that ${ }^{18} \mathrm{~F}-\mathrm{FDG}$ can be prepared from an $O$ acetylated mannose triflate (Fig. 1E) in sufficient yield, a corresponding $O$-acetylated glucose triflate (precursor-2, Fig. 1D) could be a candidate precursor of ${ }^{18} \mathrm{~F}-\mathrm{FDM}$. However, the present study revealed that only a trace amount of ${ }^{18} \mathrm{~F}-\mathrm{FDM}$ was obtained from precursor-2. On the basis of the $S_{N} 2$ reaction mechanism, the axial leaving group of the ${ }^{18} \mathrm{~F}$-FDG precursor is suitable for the nucleophilic attack of fluoride, whereas the equatorial leaving group of precursor-2 is not. In addition, as suggested in a study using tetrabutylammonium fluoride and precursor-2 (14), an unwanted side reaction between ${ }^{18} \mathrm{~F}$-fluoride and the acetoxy groups neighboring the triflate group might predominate in the ${ }^{18} \mathrm{~F}-\mathrm{FDM}$ synthesis. To avoid this side reaction, we considered that the hydroxyl-protecting groups adjacent to the triflate group should be stable to ${ }^{18} \mathrm{~F}$-fluoride. Therefore, we prepared 4,6-O-benzylidene3- $O$-ethoxymethyl-1- $O$-methyl-2- $O$-trifluoromethanesulfonyl- $\beta$-Dglucopyranoside, precursor-1, as a new precursor for ${ }^{18} \mathrm{~F}-\mathrm{FDM}$ synthesis.

Using this precursor, we synthesized ${ }^{18} \mathrm{~F}-\mathrm{FDM}$ in satisfactory yields $(50 \%-68 \%)$ that were nearly comparable with those seen with ${ }^{18}$ F-FDG synthesis. The estimated SA of ${ }^{18} \mathrm{~F}-\mathrm{FDM}$ in the present study $(>37 \mathrm{~GB} / \mu \mathrm{mol})$ was much higher than that reported

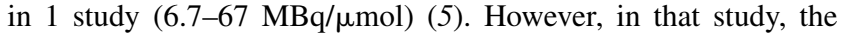

FDM concentration of injection $(0.55-5.5 \mu \mathrm{g} / \mathrm{mL})$ was far lower than the blood-glucose level in rats $(\approx 1 \mathrm{mg} / \mathrm{mL}(21))$. Therefore, the difference in SAs between ${ }^{18} \mathrm{~F}-\mathrm{FDM}$ might have had little effect on the in vivo experiments. The method used in the present study afforded improved isolated yields of ${ }^{18} \mathrm{~F}-\mathrm{FDM}$ and a shorter synthesis time in comparison with the results reported by Luxen et al. (13). The results of the present study suggest that the synthesis method using a new precursor enables preparation of a sufficient amount of ${ }^{18} \mathrm{~F}-\mathrm{FDM}$ for routine clinical use.

Uptake in AH109A cells was inhibited by D-glucose in a dosedependent manner. These findings suggested that the mechanism of uptake of ${ }^{18}$ F-FDM was related to GLUT1, similar to the mechanism of D-glucose and ${ }^{18} \mathrm{~F}$-FDG. Additionally, the in vitro enzyme assay clearly demonstrated that ${ }^{18} \mathrm{~F}-\mathrm{FDM}$ is also a good substrate for hexokinase ${ }^{18} \mathrm{~F}-\mathrm{FDG}$, as reported previously $(1,2)$. However, the $\mathrm{IC}_{50}$ value obtained by $\mathrm{D}$-glucose for ${ }^{18} \mathrm{~F}-\mathrm{FDM}$ was greater than that for ${ }^{18} \mathrm{~F}-\mathrm{FDG}$, and the fraction of ${ }^{18} \mathrm{~F}$-FDG6-P increased with a slightly slower initial speed than that by ${ }^{18} \mathrm{~F}$ FDM. We speculate that these effects on ${ }^{18}$ F-FDG were caused by unlabeled ingredients such as pyranose derivatives in the ${ }^{18} \mathrm{~F}-\mathrm{FDG}$ injection (22) because the ${ }^{18}$ F-FDG injection was used without HPLC purification. In the case of in vivo experiments, the ingredients would have little effect because of the effect of blood glucose; Figure $6 \mathrm{C}$ shows no difference in qSUV in muscle between ${ }^{18} \mathrm{~F}-\mathrm{FDM}$ and ${ }^{18} \mathrm{~F}$-FDG.

We then revealed that ${ }^{18} \mathrm{~F}-\mathrm{FDM}$ was metabolized to the major metabolite of ${ }^{18}$ F-FDM-6-P and other, unknown metabolites in

TABLE 5

Data Comparison of Uptake of ${ }^{18} \mathrm{~F}-\mathrm{FDM}$ and ${ }^{18} \mathrm{~F}-\mathrm{FDG}$ into Tissues and Tumors

\begin{tabular}{|c|c|c|c|}
\hline \multirow[b]{2}{*}{ Organ } & \multicolumn{3}{|c|}{ Uptake at $60 \mathrm{~min}^{\star}$} \\
\hline & ${ }^{18} \mathrm{~F}-\mathrm{FDM}$, present study & ${ }^{18} \mathrm{~F}-\mathrm{FDM}, 1982^{\dagger}$ & ${ }^{18} \mathrm{~F}-\mathrm{FDG}, 1982^{\dagger}$ \\
\hline Blood & $0.11 \pm 0.02(19.7 \pm 1.7)$ & $0.09 \pm 0.03(29.4)$ & $0.12 \pm 0.02(22.1)$ \\
\hline Liver & $0.21 \pm 0.03(10.3 \pm 0.8)$ & $0.29 \pm 0.06(9.1)$ & $0.14 \pm 0.02(18.9)$ \\
\hline Small intestine & $0.58 \pm 0.24(10.2 \pm 1.7)$ & $0.84 \pm 0.23(3.2)$ & $1.23 \pm 0.39(2.2)$ \\
\hline Muscle & $0.12 \pm 0.04(21.2 \pm 8.2)$ & $0.49 \pm 0.15(5.4)$ & $0.41 \pm 0.17(6.5)$ \\
\hline Brain & $1.42 \pm 0.10(1.4 \pm 0.2)$ & $1.23 \pm 0.42(2.2)$ & $1.90 \pm 0.30(1.4)$ \\
\hline Tumor & $2.17 \pm 0.32(-)$ & $2.65 \pm 0.81(-)$ & $2.65 \pm 0.61(-)$ \\
\hline \multicolumn{4}{|c|}{$\begin{array}{l}\text { *\%ID/g mean } \pm \text { SD. } \\
{ }^{\dagger} \text { Reference (5). }\end{array}$} \\
\hline
\end{tabular}


tumor cells. These results suggest that ${ }^{18} \mathrm{~F}-\mathrm{FDM}$ accumulates in tumor cells through a metabolic trapping mechanism such as the one seen with ${ }^{18} \mathrm{~F}$-FDG. With respect to ${ }^{18} \mathrm{~F}$-FDG metabolism, ${ }^{18}$ F-fluorodeoxy-6-phospho-D-gluconolactone and ${ }^{18} \mathrm{~F}$-fluorodeoxy6-phospho-D-gluconate were observed in squamous carcinoma and mammary carcinoma in mice in addition to the major metabolite of ${ }^{18}$ F-FDG-6-P at $1-3 \mathrm{~h}$ after injection (23). Furthermore, conversion of FDG-6-P into FDM-6-P or vice versa within sarcoma cells (24) or colon26 cells (25) has been reported. Therefore, further metabolism studies for ${ }^{18} \mathrm{~F}-\mathrm{FDM}$ in tumors and in normal tissues are necessary.

The results of our biodistribution study were almost consistent with our previous biodistribution studies using the same rat strain and AH109A tumor cells (Table 5) (5), but tumor uptake in the present study was slightly lower than that in the previous study. One reason might be due to the differences of rat substrains used in the present study. We previously used the Suzuki-A Donryu rat, a substrain of the Donryu rat in which AH109A cells grew well. The Suzuki-A Donryu rat strain is no longer available, so we used conventional Donryu rats in the present study. The biodistribution studies demonstrated the highest ${ }^{18}$ F-FDM uptake in AH109A tumor cells, relatively high uptake in the brain, and lower uptake in the other normal organs, indicating that ${ }^{18} \mathrm{~F}-\mathrm{FDM}$ could be an effective tumorimaging agent. However, uptake of ${ }^{18} \mathrm{~F}-\mathrm{FDM}$ in the liver was slightly higher than that of ${ }^{18} \mathrm{~F}-\mathrm{FDG}$ (Table 5), suggesting a potential disadvantage of ${ }^{18} \mathrm{~F}-\mathrm{FDM}$ for the imaging of liver tumors using PET.

Braun et al. (26) measured cerebral metabolic rates for glucose in baboons with PET using ${ }^{18} \mathrm{~F}$-FDM. There was a $20 \%$ reduction in glucose use, compared with ${ }^{18} \mathrm{~F}-\mathrm{FDG}$, if ${ }^{18} \mathrm{~F}-\mathrm{FDM}$ was used as a glucose analog. Wienhard et al. (27) also reported that the lumped constant for ${ }^{18} \mathrm{~F}-\mathrm{FDM}$ was $20 \%$ lower than that for ${ }^{18} \mathrm{~F}-\mathrm{FDG}$ in the human brain. The PET study described here also confirmed that the uptake of ${ }^{18} \mathrm{~F}-\mathrm{FDM}$ in the brain was significantly lower $(28 \%)$ than that of ${ }^{18} \mathrm{~F}-\mathrm{FDG}$, whereas ${ }^{18} \mathrm{~F}$ FDM showed no significant difference in tumor uptake, compared with that seen with ${ }^{18} \mathrm{~F}$-FDG. Therefore, a relatively lower uptake in normal brain tissue without change in tumor uptake could be an advantage of ${ }^{18} \mathrm{~F}$-FDM for the visualization of brain tumors as compared with imaging using ${ }^{18} \mathrm{~F}-\mathrm{FDG}$. In particular, low-grade glioma often exhibits low uptake of ${ }^{18} \mathrm{~F}-\mathrm{FDG}$ in tumor tissue similar to or less than that in the normal brain, resulting in a decrease in the sensitivity of lesion detection (28). However, given that ${ }^{18} \mathrm{~F}-\mathrm{FDM}$ shows $30 \%$ lower uptake in normal brain and the same uptake in tumor in comparison to ${ }^{18} \mathrm{~F}-\mathrm{FDG}$, the tumor-to-normal brain ratio of ${ }^{18} \mathrm{~F}-\mathrm{FDM}$ will become higher by $\approx 40 \%$ than that of ${ }^{18} \mathrm{~F}$-FDG. It would be worth verifying whether ${ }^{18} \mathrm{~F}$-FDM PET improves the sensitivity of detection of brain tumors.

With regard to the imaging of inflammation, the qSUVs of ${ }^{18} \mathrm{~F}-\mathrm{FDM}$ and ${ }^{18} \mathrm{~F}-\mathrm{FDG}$ were less than half of the uptake seen in tumors. However, this finding does not indicate that ${ }^{18} \mathrm{~F}$ FDM has an advantage for the differential diagnosis between cancer and inflammation. Macroautoradiography of inflammatory tissue revealed that ${ }^{18} \mathrm{~F}$-FDM accumulated as much as ${ }^{18} \mathrm{~F}$ FDG in inflammatory cells and granulation tissues (data not shown). Relatively low uptake in PET might be due to a partial-volume effect because these inflammatory and granulation tissues were thin.

\section{CONCLUSION}

We successfully synthesized ${ }^{18}$ F-FDM by a nucleophilic substitution reaction in high radiochemical yield and purity. ${ }^{18} \mathrm{~F}$ FDM showed high accumulation in tumors, lower uptake in the brain than that of ${ }^{18} \mathrm{~F}-\mathrm{FDG}$, and rapid excretion from the blood, indicating promising characteristics for cancer imaging. Additionally, we elucidated (at least in part) the mechanism of cellular uptake and metabolism of ${ }^{18} \mathrm{~F}$-FDM. ${ }^{18} \mathrm{~F}$-FDM has almost the same excellent potential as ${ }^{18} \mathrm{~F}-\mathrm{FDG}$ for PET in oncology, with an advantage of better imaging of brain tumors. We are continuing further research of ${ }^{18} \mathrm{~F}-\mathrm{FDM}$ for clinical use, including development of an automated radiosynthesis system and estimation of acute toxicity and radiation doses.

\section{DISCLOSURE}

The costs of publication of this article were defrayed in part by the payment of page charges. Therefore, and solely to indicate this fact, this article is hereby marked "advertisement" in accordance with 18 USC section 1734 . This study was supported by a Grantin-Aid for Scientific Research (grant nos. 19390312 and 23650610) from the Japanese Ministry of Education, Culture, Sports, Science and Technology and supported in part by a Grant-in-Aid for Cancer Research from the Japanese Ministry of Health, Labour and Welfare and by the Program for Promotion of Fundamental Studies in Health Sciences of the National Institute of Biomedical Innovation. No other potential conflict of interest relevant to this article was reported.

\section{REFERENCES}

1. Bessell EM, Foster AB, Westwood JH. The use of deoxyfluoro-D-glucopyranoses and related compounds in a study of yeast hexokinase specificity. Biochem J. 1972;128:199-204.

2. Bessell EM, Thomas P. The deoxyfluoro-D-glucopyranose 6-phosphates and their effect on yeast glucose phosphate isomerase. Biochem J. 1973;131:77-82.

3. Sols A, Crane RK. Substrate specificity of brain hexokinase. J Biol Chem. 1954;210:581-595.

4. Som P, Atkins HL, Bandoypadhyay D, et al. A fluorinated glucose analog, 2fluoro-2-deoxy-D-glucose (F-18): nontoxic tracer for rapid tumor detection. J Nucl Med. 1980;21:670-675.

5. Fukuda H, Matsuzawa T, Abe Y, et al. Experimental study for cancer diagnosis with positron-labeled fluorinated glucose analogs: $\left[{ }^{18} \mathrm{~F}\right]-2$-fluoro-2-deoxy-Dmannose-a new tracer for cancer detection. Eur J Nucl Med. 1982;7:294-297.

6. Kubota K. From tumor biology to clinical PET: a review of positron emission tomography (PET) in oncology. Ann Nucl Med. 2001;15:471-486.

7. Fischer BM, Mortensen J, Hojgaard L. Positron emission tomography in the diagnosis and staging of lung cancer: a systematic, quantitative review. Lancet Oncol. 2001;2:659-666.

8. Poeppel TD, Krause BJ, Heusner TA, Boy C, Bockisch A, Antoch G. PET/CT for the staging and follow-up of patients with malignancies. Eur J Radiol. 2009;70:382-392.

9. Wahl RL, Jacene H, Kasamon Y, Lodge MA. From RECIST to PERCIST: evolving considerations for PET response criteria in solid tumors. $\mathrm{J}$ Nucl Med. 2009;50(suppl 1):122S-150S.

10. Ido T, Wan $\mathrm{CN}$, Casella V, et al. Labelled 2-deoxy-D-glucose analogs ${ }^{18} \mathrm{~F}$-labelled 2-deoxy-2-fluoro-D-glucose, 2-deoxy-2-fluoro-D-mannose and ${ }^{14} \mathrm{C}-2$ deoxy-2-fluoro-D-glucose. J Labelled Comp Radiopharm. 1978;14:175-183.

11. Hamacher K, Coenen HH, Stocklin G. Efficient stereospecific synthesis of nocarrier-added 2-[18 $\mathrm{F}]$-fluoro-2-deoxy-D-glucose using aminopolyether supported nucleophilic substitution. J Nucl Med. 1986;27:235-238.

12. Hamacher K, Coenen HH, Stöcklin G. Stereospecific synthesis of N.C.A. $2-\left[{ }^{18} \mathrm{~F}\right]$ fluoro-2-deoxy-D-mannose and 2-[ $\left.{ }^{18} \mathrm{~F}\right]$ fluoro-2-deoxy-D-glucose and the influence of added carrier (KF) on FDG-synthesis. J Labelled Comp Radiopharm. 1986;23:1095-1097.

13. Luxen A, Satyamurthy N, Bida GT, Barrio JR. Stereospecific approach to the synthesis of $\left[{ }^{18} \mathrm{~F}\right] 2$-deoxy-2-fluoro-D-mannose. Int $J$ Rad Appl Instrum [A]. 1986;37:409-413. 
14. Binkley RW, Ambrose MG, Hehemann DG. Reactions of per-O-acetylated carbohydrate triflates with halide ions. J Carbohydr Chem. 1987;6:203-219.

15. Brown LJ, Bouvet DR, Champion S, et al. A solid-phase route to ${ }^{18} \mathrm{~F}$-labeled tracers, exemplified by the synthesis of $\left[{ }^{18} \mathrm{~F}\right] 2$-fluoro-2-deoxy-D-glucose. Angew Chem Int Ed Engl. 2007;46:941-944.

16. Furumoto S, Shinbo R, Ishikawa Y, Yanai K, Iwata R, Fukuda H. Characterization of 2-[18 F]fluoro-2-deoxy-D-mannose ([18 F]FDM) as a tumor imaging agent. J Labelled Comp Radiopharm. 2011;54:S226.

17. Furumoto S, Shinbo R, Yoshioka T, et al. Synthesis and preliminary evaluation of $\left[{ }^{18}\right.$ F]FDM for tumor imaging. J Labelled Comp Radiopharm. 2009;52: S186.

18. Rijn CJSV, Herscheid JCM, Visser GWM, Hoekstra A. On the stereoselectivity of the reaction of $\left[{ }^{18} \mathrm{~F}\right]$ acetylhypofluoride with glucals. Int J Appl Radiat Isot. 1984;36:111-115.

19. Odashima S. Establishment of ascites hepatomas in the rat, 1951-1962. Natl Cancer Inst Monogr. 1964;16:51-93.

20. Mizuta T, Kitamura K, Iwata H, et al. Performance evaluation of a high-sensitivity large-aperture small-animal PET scanner: ClairvivoPET. Ann Nucl Med. 2008;22:447-455.

21. Kubota K, Kubota R, Yamada S, Tada M, Takahashi T, Iwata R. Re-evaluation of myocardial FDG uptake in hyperglycemia. J Nucl Med. 1996;37:1713-1717.
22. Alexoff DL, Casati R, Fowler JS, et al. Ion chromatographic analysis of high specific activity ${ }^{18}$ FDG preparations and detection of the chemical impurity 2deoxy-2-chloro-D-glucose. Int J Rad Appl Instrum [A]. 1992;43:1313-1322.

23. Kaarstad K, Bender D, Bentzen L, Munk OL, Keiding S. Metabolic fate of ${ }^{18} \mathrm{~F}-$ FDG in mice bearing either SCCVII squamous cell carcinoma or C3H mammary carcinoma. J Nucl Med. 2002;43:940-947.

24. Kojima M, Kuribayashi S, Kanazawa Y, Haradahira T, Maehara Y, Endo H. Metabolic pathway of 2-deoxy-2-fluoro-D-glucose and 2-deoxy-2-fluoro-D-mannose in mice bearing sarcoma 180 studied by fluorin-19 nuclear magnetic resonance. Chem Pharm Bull (Tokyo). 1988;36:1194-1197.

25. Shimmura T, Nemoto M, Ino S, Kurami M. Metabolism of ${ }^{18}$ F-FDG (2-fluoro-2deoxy-D-glucose) in tumor cells [in Japanese]. Kaku Igaku. 2003;40:31-38.

26. Braun AR, Carson RE, Adams HR, Finn RD, Francis BE, Herscovitch P. A kinetic comparison of $\left[{ }^{18} \mathrm{~F}\right] 2$-fluoro-2-deoxyglucose and $\left[{ }^{18} \mathrm{~F}\right]$ 2-fluoro-2-deoxymannose using positron emission tomography. Nucl Med Biol. 1994;21:857-863.

27. Wienhard K, Pawlik G, Nebeling B, et al. Estimation of local cerebral glucose utilization by positron emission tomography: comparison of $\left[{ }^{18} \mathrm{~F}\right] 2$-fluoro-2deoxy-D-glucose and $\left[{ }^{18} \mathrm{~F}\right] 2$-fluoro-2-deoxy-D-mannose in patients with focal brain lesions. J Cereb Blood Flow Metab. 1991;11:485-491.

28. Chen W. Clinical applications of PET in brain tumors. J Nucl Med. 2007;48:1468-1481. 